Undas Vol 12. , Nomor 1, Juni $2016: 61--74$

\title{
FUNGSI DAN PERAN KELUARGA DALAM NOVEL IBUK KARYA IWAN SETYAWAN
}

\author{
Role and Function of Family in an Ibuk Novel by Iwan Setyawan
}

\author{
Nidya Triastuti Patricia \\ Balai Bahasa Kalimantan Selatan \\ Jalan Jenderal Ahmad Yani Km 32,2, Loktabat, Banjarbaru 70712 Kalimantan Selatan \\ Telepon (0511) 4772641, Pos-el:
}

\begin{abstract}
Abstrak: Novel Ibuk bercerita tentang keluarga sederhana yang bahu membahu bekerja keras untuk mendapat pendidikan yang lebih baik agar mampu memperoleh kehidupan yang lebih baik. Penelitian ini dilakukan untuk menjawab pertanyaan bagaimana fungsi dan peran keluarga dalam novel Ibuk karya Iwan Setyawan. Tujuan penelitian ini adalah untuk mendeskripsikan fungsi dan peran keluarga yang terdapat dalam novel Ibuk karya Iwan Setyawan. Data primer yang digunakan dalam penelitian ini berupa novel Ibuk karya Iwan Setyawan. Metode yang digunakan dalam penelitian ini ialah metode deskriptif kualitatif dengan pendekatan sosiologi sastra. Berdasarkan analisis data dapat diketahui bahwa keluarga dalam novel Ibuk karya Iwan Setyawan menunjukkan fungsi biologis, psikologis, sosial budaya, sosial, dan pendidikan. Kemudian, anggota keluarga yakni Bapak, Ibu dan kelima anaknya Isa, Nani, Bayek, Rini dan Mira menjalankan perannya masing-masing dengan baik.
\end{abstract}

Kata kunci: Fungsi dan peran keluarga, novel Ibuk, sosiologi sastra.

Abstract: Novel Ibuk talks about average family who work together to get higher education so that they will get better life. This study is done to answer a question what the function and the role of family in novel Ibuk by Iwan Setyawan. The aim of this study is to describe the function and the role of family in novel Ibuk by Iwan Setyawan. The main data which is used in this study is in the form of novel Ibuk by Iwan Setyawan. This study uses descriptive qualitative method with sociology of literature approach. Based on the data analysis, it is found out that family in the novel Ibuk by Iwan Setyawan shows biology, psychology, social culture, social, and educaton function. Then, the family member, they are father, mother and five of their children Isa, Nani, Bayek, Rini and Mira have their own role well.

Key words: The function and family role, Ibuk novel, sociology of literature.

\section{PENDAHULUAN}

Banyak novel bertema keluarga yang menceritakan jalinan hubungan antar anggota keluarga. Keluarga bisa terdiri dari ayah, ibu, dan anak; ayah dan anak, atau ibu dan anak. Salah satu novel bertema keluarga adalah novel Ibuk karya Iwan Setyawan.
Novel Ibuk bercerita tentang keluarga sederhana yang terdiri dari sepasang suami istri bersama lima anak. Bapak, Ibuk, Isa, Nani, Bayek, Rini dan Mira menjalani hidup dalam kesederhanaan dan keprihatinan. Mereka bersamasama berjuang bahu membahu melalui gelombang hidup untuk memperoleh kehidupan yang lebih baik. Tekad Ibuk 
agar anak-anaknya bisa terus sekolah, tidak seperti dirinya yang tidak lulus $\mathrm{SD}$, merupakan senjata terkuat yang mendorong keluarga tersebut untuk terus bergerak maju. Melalui perjuangan keras, akhirnya anak-anak Ibuk bisa meraih pendidikan sampai perguruan tinggi sehingga derajat keluarga pun ikut terangkat.

Novel Ibuk menarik untuk diteliti. Oleh karena itu, penelitian ini dilakukan untuk menjawab pertanyaan bagaimana fungsi keluarga dalam novel Ibuk karya Iwan Setyawan dan bagaimana peran anggota keluarga dalam novel Ibuk karya Iwan Setyawan. Tujuan penelitian ini adalah untuk mendeskripsikan fungsi dan peran keluarga yang terdapat di dalam novel Ibuk karya Iwan Setyawan.

Penelitian terhadap novel Ibuk pernah dilakukan oleh Julianto dengan bentuk skipsi S1 dengan judul Citra Perempuan dalam Novel Ibuk karya Iwan Setyawan dan Kelayakannya Sebagai Bahan Ajar Sastra di SMA. Penelitian dititikberatkan pada penelitian tokoh wanita di novel yakni Ibuk. Sepengetahuan peneliti, belum ada penelitian terhadap novel Ibuk dengan titik berat penelitian terhadap fungsi dan peran keluarga. Oleh karena itu, penelitian ini dilakukan untuk melengkapi penelitian terhadap novel Ibuk karya Iwan Setyawan.

\section{KERANGKA TEORI}

Asumsi dasar penelitian sosiologi sastra adalah sastra tidak lahir dalam kekosongan sosial. Sastra adalah ekspresi kehidupan manusia yang tak lepas dari akar masyarakatnya. Aspek- aspek kehidupan sosial akan memantul penuh ke dalam karya sastra (Endraswara, 2003:78).

Sosiologi sastra adalah konsep cermin (mirror). Sosiologi berusaha mencari pertautan antara sastra dengan kenyataan masyarakat. Karena penelitian ini ingin membahas fungsi dan peran keluarga dalam novel Ibuk karya Iwan Setyawan, penelitian dianggap cocok menggunakan pendekatan sosiologi sastra.

Keluarga merupakan unit terkecil dari masyarakat. Keluarga berasal dari bahasa Sansekerta yakni kula dan warga. Kulawarga memiliki arti "anggota" dan "kelompok kerabat". Keluarga adalah lingkungan di mana beberapa orang yang masih memiliki hubungan darah, bersatu.

alvian.blogspot.co.id)

(http:/ / fajar-

Menurut Departemen Kesehatan RI (1998), keluarga adalah unit terkecil dari masyarakat yang terdiri atas kepala keluarga dan beberapa orang yang terkumpul dan tinggal di suatu tempat di bawah suatu atap dalam keadaan saling

ketergantungan. (http:/ / citrarhmdn.blogspot.co.id)

Keluarga inti atau sering juga disebut keluarga batih terdiri dari ayah, ibu, dan anak-anak. Keluarga merupakan sekolah pertama anak. Melalui keluarga, anak manusia belajar hidup dan kehidupan.

Dalam tatanan masyarakat, terdapat beberapa fungsi keluarga yaitu: fungsi biologis, fungsi psikologis, fungsi sosial budaya atau sosiologi, fungsi sosial, dan fungsi pendidikan.

Adapun fungsi biologis yakni untuk meneruskan keturunan, memelihara dan membesarkan anak, memberikan 
makanan bagi keluarga dan memenuhi kebutuhan gizi, merawat dan melindungi kesehatan para anggotanya, dan memberi kesempatan untuk berekreasi. Fungsi psikologis yaitu identitas keluarga serta rasa aman dan kasih sayang, pendewasaan kepribadian bagi para anggotanya, perlindungan secara psikologis, serta mengadakan hubungan keluarga dengan keluarga lain atau masyarakat. Fungsi sosial budaya atau sosiologi yakni meneruskan nilai-nilai budaya, sosialisasi, dan pembentukan normanorma, tingkah laku pada tiap tahap perkembangan anak serta kehidupan keluarga. Fungsi sosial yakni mencari sumber-sumber untuk memenuhi fungsi lainnya, pembagian sumber-sumber tersebut untuk pengeluaran atau tabungan, dan pengaturan ekonomi atau keuangan. Fungsi terakhir, fungsi pendidikan yakni penanaman keterampilan, tingkah laku dan pengetahuan dalam hubungan dengan fungsi-fungsi lain, persiapan untuk kehidupan dewasa, dan memenuhi peranan sehingga anggota keluarga yang (http://www.kajianpustaka.com)

Peranan keluarga menggambarkan seperangkat perilaku interpersonal, sifat, kegiatan yang berhubungan dengan individu dalam posisi dan situasi tertentu. Peranan individu dalam keluarga didasari oleh harapan dan pola perilaku dari keluarga, kelompok dan masyarakat.

Berbagai peranan yang terdapat di dalam keluarga adalah peranan ayah, peranan ibu dan peranan anak. Peranan ayah yakni ayah sebagai suami dari istri dan anak-anak; ayah berperan sebagai pencari nafkah, pendidik, pelindung dan pemberi rasa aman; sebagai kepala keluarga; sebagai anggota dari kelompok sosialnya serta sebagai anggota dari kelompok sosialnya serta sebagai anggota masyarakat dari lingkungannya.

Peranan ibu yakni sebagai istri dan ibu dari anak-anaknya, ibu mempunyai peranan untuk mengurus rumah tangga, sebagai pengasuh dan pendidik anakanaknya, pelindung dan sebagai salah satu kelompok dari peranan sosialnya serta sebagai anggota masyarakat dari lingkungannya, disamping itu juga ibu dapat berperan sebagai pencari nafkah tambahan dalam keluarganya. Kemudian, peranan anak yakni anakanak melaksanakan peranan psikosial sesuai dengan tingkat perkembangannya baik fisik, mental, sosial, dan spiritual. (https://id.wikipedia.org)

\section{METODE PENELITIAN}

Metode yang digunakan dalam penelitian ini adalah deskriptif kualitatif. Menurut Endraswara (2004:5) yang paling cocok bagi fenomena sastra adalah penelitian kualitatif karena deskriptif. Hal tersebut didukung oleh Ratna (2004:47) yang menyatakan metode kualitatif memberikan perhatian terhadap data alamiah.

Teknik yang digunakan dalam pengumpulan data adalah studi pustaka. Dalam ilmu sastra, sumber datanya adalah karya atau naskah, dan data penelitiannya sebagai data formal adalah kata-kata, kalimat dan/atau wacana.

Data utama dari penelitian ini adalah novel Ibuk karya Iwan Setyawan terbitan 
PT. Gramedia Pustaka Utama, Jakarta, tahun 2012. Data pendukung diambil dari berbagai sumber yang berhubungan dengan masalah penelitian.

\section{ANALISIS DAN PEMBAHASAN}

Fungsi keluarga dalam novel Ibuk mencakup fungsi biologis, psikologis, sosial budaya, sosial, dan pendidikan. Adapun analisisnya sebagai berikut.

Fungsi pertama adalah fungsi biologis. Salah satu fungsi biologis keluarga adalah untuk meneruskan keturunan. Setelah menikah Bapak dan Ibuk dikarunia lima orang anak. Anak pertama dipanggil Isa. Pada saat Isa berumur 6 bulan, Ibuk hamil anak kedua. Anak kedua ini diberi nama Nani.

Di umur Nani yang ketujuh bulan, Ibuk hamil lagi. Bapak dan Ibuk mengharapkan anak laki-laki setelah memiliki dua anak perempuan. Namun, kali ini Ibuk keguguran. Hal ini ditunjukkan kutipan berikut.

Di bulan ketiga, ketika mencuci baju di belakang rumah, Ibuk merasa sesuatu mengalir di kakinya. Ada darah menetes di betisnya. Ia segera pergi ke bidan. Ternyata Ibuk keguguran.... Harapan Bapak untuk menggendong anak laki-laki gugur bersama gugurnya janin di rahim Ibuk. (hl. 35)

Enam bulan setelah keguguran, Ibuk hamil lagi. Kali ini Ibuk melahirkan anak laki-laki. Anak yang diharapharapkan ini dipanggil Bayek. Kemudian, Bapak dan Ibuk dikarunia dua anak perempuan lagi sebagaimana kutipan berikut.

Hidup Bapak, Ibuk, Isa, Nani dan Bayek semakin ramai dengan kelahiran Rini, adik Bayek. Ia lahir satu setengah Bayek lahir. Menyusul Mira, anak bungsu yang lahir lima tahun setelah kelahiran Rini. (hl. 36)

Bapak dan Ibuk memelihara dan membesarkan anak dengan sebaikbaiknya. Hal tersebut digambarkan melalui kutipan berikut. "Lima orang sudah terlahir. Mereka adalah cahaya paling terang dalam hidup Ibuk. Ia menjaga mereka pagi, siang, dan malam. Tanpa jeda. Tanpa lelah" (hl. 36).

Dalam memelihara anak-anaknya, Bapak dan Ibuk berusaha agar anakanaknya selalu terpenuhi kebutuhan pangannya. Kutipan di bawah ini menunjukkan usaha mereka.

Ketika Bapak sakit dan tak ada setoran uang belanja, Ibuk biasanya menggadaikan barang-barang di rumah, seperti piring, cangkir, atau jariknya. Dapur harus mengepul. Anak-anak harus makan. (hl. 37)

Selain itu, Bapak dan Ibuk tidak hanya sekedar memberi makan, mereka juga berusaha memenuhi kebutuhan gizi anak-anaknya. Sebagaimana kutipan berikut.

"Empal daging itu kesukaan Bapak. Lauk yang sangat mewah dan hanya Ibuk hidangkan kalau ada bonus dari Bapak... "Satu satu ya. Ibuk cuma punya tujuh iris," pesan Ibuk. (hl. 47).

Bapak juga sering bawa susu segar dari Pujon. (hl. 48)

Selain roti meises cokelat dari juragannya, Bapak kadang membawa pulang nasi goreng, $\mathrm{mi}$ goreng, sate ayam, sate kambing, atau sate kelinci yang dibeli di warung dekat rumah. (hl. 96)

Kutipan tersebut menunjukkan bahwa walaupun tidak sering, namun 
anak-anak bisa merasakan menu empal daging. Mereka juga bisa meminum susu dan makanan -makanan selain masakan Ibuk di rumah.

Bila anak-anak sakit, seperti pilek atau batuk, Ibuk akan membelikan Bodrexin untuk semua anaknya. Hal ini dilakukan karena satu anak yang sakit akan menulari anak yang lain. Namun, bila parah dan perlu berobat, Ibuk tidak segan membawa anaknya ke dokter seperti kutipan berikut. "Ketika Bayek sakit amadel atau Isa sesak napas, Ibuk baru membawa mereka ke dokter" (h.37).

Anak-anak juga pernah pergi rekreasi ke pantai sewaktu Bapak menjadi sopir pribadi. Atau melakukan hal sederhana, "Tamasya mereka adalah ikut Bapak narik angkot ke Malang dan menurunkan penumpang di malam hari di kota Pujon" (hl. 97). Hal-hal tersebut menggambarkan bahwa keluarga Ibuk menjalan fungsi biologis dengan baik.

Fungsi keluarga berikutnya adalah fungsi psikologis. Walaupun keluarga Ibuk bukan keluarga kaya namun fungsi psikologis keluarga terpenuhi dengan baik. Bapak dan Ibuk melimpahi anakanaknya dengan kasih sayang. Anakanaknya yang ingin terus sekolah didukung penuh oleh Bapak dan Ibuk. Kutipan-kutipan berikut menujukkan hal tersebut.

“Uang SPP. “Oh, besok tanggal 10 ya? Besok ya, Yek. Besok. Pasti ono kok!" kata Ibuk, memeriksa lembaran berisi laporan SPP. Selama ini Ibuk tak pernah telat membayar SPP semua anaknya. "Prioritas utama!" katanya." (hl. 60) "Bayek juga, mesti ke SMP 1 terus ke SMA 1 Batu, dan kuliah. Anakanak perempuan juga, mesti kuliah!
Gak cukup sampai SMP atau SMA saja. Biar kamu dapat kerjaan yang bagus." (hl. 66)

Tingkah laku, tindakan dan ucapan Ibuk meyakinkan anak-anak bahwa mereka akan bisa terus sekolah. Tidak hanya sekolah dasar tapi sampai jenjang pendidikan tertinggi yang bisa mereka raih. Hal ini membuat anak-anak secara psikologis merasa aman dan terjamin.

Hidup dalam kesederhanaan dan keprihatinan membuat anak-anak lebih berkembang kepribadiannya. Dengan keterbatasan sarana dan prasarana, anak-anak tetap berprestasi di sekolah. Padahal tidak ada tuntutan agar mereka belajar atau berprestasi. Semua terjadi karena kesadaran mereka sendiri. Hal ini tersirat dari kutipan berikut.

Ibuk dan bapak tak pernah menentukan aturan kapan dan berapa lama anak-anak harus belajar. Isa dan adik-adiknya telah membuka hati mereka sendiri. Membuka buku mereka sendiri. Ibuk dan Bapak telah bekerja sepenuh hati untuk memenuhi kebutuhan sekolah mereka.... Mungkin anak-anak ini tersentuh oleh hidup Bapak dan Ibuk yang sederhana dan penuh keprihatinan. Isa dan adik-adiknya ingin berjuang seperti mereka. Ingin memberikan cinta yang penuh kepada orangtuanya. (hl. 64-65)

Kutipan tersebut menunjukkan bahwa secara mental, anak-anak tumbuh dan berkembang dengan baik.

Selain Bapak dan Ibuk, anak-anak juga dekat dengan kakek mereka, yang biasa dipanggil Bapak Mun. Bapak Mun biasa memberikan uang jajan lima puluh rupiah kepada cucunya setiap hari. Pada tahun 80-an, uang lima puluh rupiah merupakan sejumlah uang yang besar. 
Uang jajan dari Bapak Mun merupakan kebahagiaan tersendiri bagi cucucucunya, seperti tergambar melalui kutipan berikut. "Bapak Mun, jatah yang kemarin belum dikasih ya? Jadi jatah hari ini dobel!" seru Bayek dengan wajah berbunga-bunga. (hl 113). Hal-hal tersebut menunjukkan secara psikologis, fungsi keluarga berjalan dengan baik.

Fungsi keluarga selanjutnya adalah fungsi sosial budaya. Pada fungsi sosial budaya/sosiologi ada usaha untuk meneruskan nilai-nilai budaya. Salah satu contoh yang dilakukan oleh keluarga Ibuk adalah pelaksanaan upacara khitanan Bayek yang ditunjukkan kutipan berikut.

Saat-saat yang dinantikan Bapak tiba. Anak lelaki Bapak akhirnya disunat. Bapak ingin ada perayaan besar untuk Bayek. Tak ada undangan tapi rumah Bayek dipenuhi saudara dan tetangga. Tenda warna cokelat muda dipasang di depan rumah. Kursi plastik dan meja yang disewa dari tetangga sebelah dipenuhi tamu yang menyantap rawon masakan Ibuk. Di setiap meja ada makanan kecil seperti lemper, nagasari, tetelan, pastel, dan teh manis. (hl.127)

Kutipan tersebut menggambarkan suasana perayaan sunatan Bayek. Bayek sebagai anak laki-laki satu-satunya akhirnya menjalani acara sunatan. Acara tersebut merupakan hajatan besar pertama untuk keluarga Bayek. Walaupun keluarga Bayek merupakan keluarga yang hidup dalam kesederhanaan, mereka mampu melaksanakan acara khitanan Bayek seperti pada umumnya.
Kemudian, fungsi keluarga berikutnya adalah fungsi sosial. Pada fungsi sosial ada fungsi pengeluaran atau tabungan. Hal tersebut juga ditunjukkan oleh keluarga Ibuk. Bapak dan Ibuk memang hidup dalam suasana prihatin tetapi mereka berusaha untuk tetap menabung sebagaimana tergambar pada kutipan-kurtipan berikut.

Bapak juga berusaha menabung. Tak banyak memang. Biasanya hari Sabtu atau Minggu, uang itu Bapak pakai untuk membelikan nasi goreng atau mi goreng buat anakanaknya. (hl. 46)

"Berapa pun uang yang kamu miliki, jangan berlebihan. Nabung! ...Hidupmu tidak hanya untuk sekarang saja. Hidupmu masih panjang," pesan Ibuk yang tidak punya rekening di bank. Ibuk selalu menabung di bawah tumpukan baju di lemari tua. (hl.102).

Kutipan-kutipan tersebut menyatakan bahwa Bapak dan Ibuk sadar manfaat dari menabung. Walaupun uang yang mereka miliki tidak berlebihan, mereka tetap membudayakan menabung. Budaya menabung ini juga diajarkan pada anakanak.

Selain menabung, harus ada pengaturan ekonomi atau keuangan agar kebutuhan hidup bisa terpenuhi dengan baik. Fungsi ini dijalankan Ibuk seperti ditunjukkan kutipan berikut.

"Yang penting, pastiin ada uang buat makan besok ya, Pak!" kata Ibuk selalu memastikan. Dari uang belanja ini, Ibuk berusaha menyisakan sebagian untuk membayar SPP dan keperluan sekolah. Bapak terkadang juga memakai uang tabungan Ibuk ini untuk memperbaiki angkot yang 
rusak atau ketika kena tilang polisi. Ketika mendapat banyak rezeki di jalan, Bapak akan memberi uang belanja lebih." (hl. 46)

Ibuk merupakan orang yang bertanggung jawab mengatur keuangan. Segala pengeluaran untuk kebutuhan rumah tangga diatur ibu sebaik-baiknya. Dari kebutuhan keluarga berupa makanan, kebutuhan sekolah dengan segala pernak-perniknya, keperluan angkot, bahkan keperluan hari raya seperti baju baru.

Ibuk adalah pengatur ekonomi yang handal. Ibuk akan mengatur keuangan sedemikian rupa sehingga tidak ada yang terluka ataupun kecewa sebagaimana kutipan "Ibuk memastikan tidak ada air mata dengan segala cara. Menggadaikan cincin emas, menjual baju bekas, atau hutang ke Bang Udin." (hl.102). Hal ini menunjukkan bahwa fungsi sosial keluarga dapat dijalankan dengan baik walaupun Ibuk dan juga Bapak bukanlah orang yang berpendidikan tinggi.

Fungsi yang terakhir adalah fungsi pendidikan. Dalam fungsi pendidikan ada penanaman keterampilan dan tingkah laku. Hal tersebut dapat dilihat dari kutipan berikut.

Seperti biasa, Nani membersihkan dulu. Ia menyapu lantai dan mengepel. Isa membersihkan kaca jendela dan meja kaca kecil di ruang tamu. (hl.50)

Ibuk pun sebenarnya tak pernah menyuruh anak-anaknya untuk membersihkan rumah sebelum makan siang. Isa dan Nani melakukan itu dengan sendirinya. Dua gadis kecil ini ingin membuat rumah mereka sebagi tempat ternyaman. (hl.51)
Kutipan tersebut menggambarkan anak-anak memiliki keterampilan hidup dan tingkah laku yang baik. Dalam kesederhanaan mereka berusaha melakukan hal yang terbaik yang mereka bisa, sesuai usia dan alam pikiran mereka.

Dalam persiapan untuk kehidupan dewasa, Ibuk menanamkan bahwa pendidikan adalah modal utama untuk memperoleh kehidupan yang lebih baik. Hal tersebut terungkap melalui kutipan berikut.

“Bayek juga, mesti ke SMP 1 terus ke SMA 1 Batu, dan kuliah. Anakanak perempuan juga, mesti kuliah! Gak cukup sampai SMP atau SMA saja. Biar kamu dapat kerjaan yang bagus. Biar semua bisa mandiri. Biar jadi manusia yang bermartabat," lanjut Ibuk ke adikadik Isa (hl. 66)

Kutipan tersebut menunjukkan bahwa pengetahuan tentang keutamaan pendidikan sangat ditekankan oleh Ibuk. Ibuk dan Bapak mengalami sendiri bagaimana harus menjalani hidup seadanya dengan segala keterbatasan karena minimnya pendidikan dan Ibuk tidak ingin anakanaknya mengalami hal yang sama. Halhal tersebut menunjukkan fungsi pendidikan di keluarga Ibuk berjalan dengan baik.

Adapun analisis mengenai peranan keluarga sebagai berikut. Dalam novel Ibuk ada Bapak, Ibu dan anak-anak. Setiap orang memiliki perannya masingmasing dalam sebuah keluarga. Adapun analisisnya sebagai berikut.

Bapak digambarkan sebagai sosok pekerja keras. Bapak tidak lulus SMP. Sejak belia beliau sudah mandiri dan mencari nafkah dengan menjadi kenek 
angkot. Sebagai kepala keluarga, Bapak merupakan orang yang sangat bertanggung jawab. Hal tersebut tergambar dari kutipan berikut.

Anak-anak melihat perjuangan

Bapak yang gigih lewat tangan

Bapak yang selalu berlepotan oli.

Bapak yang sering pulang tengah

malam. Kulit Bapak yang semakin gelap (hl. 142)

Kutipan tersebut menggambarkan kerja keras Bapak sebagai kepala rumah tangga dan Bapak memikulnya dengan gagah berani.

Sampai anak-anak sudah dewasa pun, Bapak selalu memperhatikan anakanaknya. Saat sudah memiliki cucu, kasih sayangnya pun tercurah untuk cucu-cucunya. Bapaklah yang mengambil tugas mengantar cucunya ke sekolah dan mengantar pergi kemana mereka suka. Untuk itu, Bapak mengantar dengan mobil Panther kesayangannya. Saat terbaring sakit karena stroke pun, Bapak masih memikirkan anak dan cucunya. Hal tersebut dapat dilihat dari kutipan berikut.

"Nah, hujan deres sekali ya di luar?" tanya Bapak.

"Nah, siapa yang mengantar cucucucu kita?" tanya Bapak. Air matanya tak terbendung lagi.

"Nah, itu dapur di rumah Nani juga bocor kemarin. Sudah dibenerin tah?" tanya Bapak.

Bapak masih gelisah. Dalam keadaan sakit ia masih memikirkan Ibuk, anak, dan cucunya. (hl. 259)

Kutipan tersebut menggambarkan betapa besar kepedulian Bapak pada keluarganya. Walaupun dalam keadaan sakit, tidak mengurangi keinginan Bapak untuk tetap mengurus orangorang yang dicintainya.
Sebagai kepala rumah tangga, Bapaklah yang mencari nafkah. Bapak bekerja sebagai sopir angkot. Dalam memenuhi kebutuhan rumah tangga, Bapak selalu melakukan hal terbaik yang ia bisa. Pada saat-saat keuangan keluarga begitu sulit, seperti saat Bayek masih kecil dan tidak bisa mengambil raport karena belum membayar uang sekolah karena mobil Bapak mogok selama empat hari dan uang habis untuk benerin angkot. Bapak berusaha sekuat tenaga mencari uang seperti kutipan berikut.

“Besok Bayek harus bayar SPP.

Sebelum ayam berkokok, Bapak sudah terbangun. Ia masih mengenakan baju yang dipakai tadi malam. Ia segera menghidupkan mesin mobil.

"Nah, aku narik dulu ya," pamit Bapak.

Pukul 10 pagi Bapak kembali ke rumah. Tak seperti biasanya. "Nah, ini segera ke sekolah Bayek. Bayar buku dan rapornya," kata Bapak. Ia menyerahkan beberapa lembar uang lima ratusan dan seribuan yang ia kumpulkan sejak pagi. (hl.69)

Kutipan

tersebut menggambarkan bahwa Bapak akan bekerja keras untuk memperoleh uang tambahan sehingga kebutuhan keluarga, khususnya untuk pendidikan anak-anaknya terpenuhi dan anak-anaknya tidak kecewa.

Bahkan pada saat Bayek diterima PMDK di IPB dan memerlukan dana yang lebih besar, Bapak bersedia menjual angkot kesayangannya. Bapak tidak ragu melakukan apapun demi kemajuan 
pendidikan anak-anaknya. Hal tersebut ditunjukkan oleh kutipan berikut.

"Yek, kita jual angkot untuk kuliah ke Bogor," tegas Ibuk lagi meyakinkan Bayek.

"Entar kita mau makan apa kalau angkot dijual?" tanya Bayek.

Beberapa saat Bapak menimpali, "Bapak akan kerja di tetangga sebelah menjadi sopir truk. Mereka lagi butuh sopir untuk membawa makanan ternak dari Batu ke Surabaya. Angkot sudah ada yang mau beli." (hl.134)

Kutipan tersebut menggambarkan Bapak merelakan mobil angkotnya dijual demi biaya pendidikan Bayek ke Bogor. Hal ini diketahui dan didukung oleh Ibuk. Bapak juga tetap bertanggung jawab sebagai kepala rumah tangga dan pencari nafkah. Beliau akan menjadi sopir truk yang berarti Bapak akan menjalani trayek yang lebih jauh dan lebih melelahkan dibandingkan menjadi sopir angkot. Namun, beliau akan menjalani hal tersebut selama bisa menafkahi dan membahagiakan keluarganya.

Bayek beserta kakak dan adiknya menyadari kerja keras Bapak dan Ibuk demi keluarga, seperti kutipan berikut. "Ada air mata di sudut mata Bayek. Bayek dan kakak adiknya tahu bagaimana Bapak dulu bekerja keras dari hari ke hari untuk membeli angkot itu. perjuangan gigih Ibuk menyisakan uang belanja untuk demi angkot itu. Bayek tahu betapa besar cinta Bapak untuk angkotnya. Kini Bapak harus menjual angkotnya. (hl.134)

Kutipan tersebut menggambarkan bahwa membeli angkot adalah sebuah perjuangan besar bagi Bapak dan Ibuk.
Namun, pendidikan anak-anak merupakan hal yang tidak bisa ditawartawar. Anak-anak tak perlu merasa kuatir, Bapak dan Ibuk akan selalu mencari solusi. Mereka percaya akan selalu ada jalan selama mereka mau berusaha. Sebagai seorang ayah, Bapak merupakan sosok yang mampu mendidik, melindungi dan memberi rasa aman pada anggota keluarganya. Beliau merupakan suri teladan untuk anak-anaknya.

Selanjutnya, Ibuk. Ia menikah dengan Bapak saat berusia 17 tahun. Bapak memberanikan diri melamar Ibuk karena sosok Ibuk dipandang sebagai orang yang cocok untuknya. Seperti ucapan Bapak saat menjelaskan kenapa ia ingin menikahi Ibuk.

"Si Ngatinah iki wonge apikan. Gak macem-macem. Bisa hidup susah seperti aku," jawab Sim.

"Cari rezeki bareng maksudku. Berjuang bareng. Anaknya gak manja. Mau bekerja keras juga," (hl.23)

Hal ini terbukti tatkala sudah menjadi istri, Ibuk terbukti menjadi sosok yang tegar, setia dan selalu bahu membahu dengan Bapak menciptakan keluarga bahagia. Kehadirannya mampu menyejukkan hati Bapak yang kalut tatkala dalam kondisi terdesak secara keuangan. "Sing sabar ae". Rezeki nggak datang hari ini tapi insya Allah akan datang besok," kata Ibuk" (hl.111). Ibuk tahu keperluan keluarga, tapi Ibuk tidak memaksakan kehendaknya pada Bapak. Ibu tahu Bapak sudah berusaha sekuat tenaga.

Sebagai seorang ibu, Ibuk adalah pendengar yang baik. Segala keluhan dari anak-anaknya dia tampung dan ia 
carikan penyelesaiannya. Seperti contoh kutipan berikut.

"Buk, sepatuku jebol!" seru Nani di depan pintu. ... "Lem yang dikasih Bapak kemarin sudah tidak kuat lagi, Buk. Tadi lepas saat pelajaran olah raga. Aku pake, eh, copot," kata Nani sambil senyum-senyum. "Oalah $\mathrm{Ni}$, sepurane Nak," kata Ibuk. (hl.86)

Ibuk yang tahu sepatu Nani sudah jebol kemudian meminjam uang pada Bang Udin agar bisa membelikan sepatu baru untuk Nani. Dia ingin anakanaknya bahagia seperti anak-anak lain.

Ibuk juga merupakan ibu yang sangat pandai mengurus rumah tangga dan menyiasati uang yang ada. Hal tersebut dapat dilihat melalui kutipan berikut.

Ibuk masih sibuk di dapur. Selalu ada yang ia kerjakan. Entah itu mencuci piring, menata peralatan dapur, mengepel lantai dapur, membersihkan lemari, menyiapkan bumbu buat masak besok, atau menyeterika baju. (hl.51)

Ia juga yang memotong rambut mereka. Ia mencoba mengerjakan urusan rumah dan sekolah sendiri. ... celana seragam yang bolong ia jahit sendiri dengan mesin jahit tua merek Singer.... Tak ada pergi ke tukang jahit, tak ada pergi ke salon. Ibuk harus pintar-pintar menyiasati uang yang ada. (hl.98)

Kutipan tersebut menunjukkan bahwa Ibuk akan melakukan apa saja agar kebutuhan rumah tangganya terpenuhi tanpa harus membebani keuangan keluarga. Keinginan untuk mengurus keluarganya dengan baik memaksa Ibuk memiliki multitalenta.

Ibuk berusaha mengurus anakanaknya sebaik mungkin. Ibu ingin agar anak-anaknya selalu sehat seperti kutipan berikut.

"Setiap kali melihat anak yang sakit, hati Ibuk seperti jatuh," kata Ibuk. Ia menatap anaknya satu-satu. "Melihat kalian sehat seperti ini adalah segalanya bagi Ibuk," (hl.85)

Hal ini menunjukkan betapa dalam perhatian Ibuk pada anak-anaknya. Ia ingin agar anak-anaknya menjaga kesehatan karena melihat anak-anaknya sehat dan ceria adalah salah satu kebahagiaan bagi Ibuk.

Ibuk adalah ibu yang baik dan sangat menyayangi anak-anaknya. Waktu kecil, Ibuk tidak lulus SD karena pada saat ujian, Ibuk jatuh sakit. Oleh karena itu, ia tidak ingin anak-anaknya mengalami hal sama seperti dirinya. Ibuk ingin agar anak-anaknya semangat sekolah agar memperoleh kehidupan yang lebih baik seperti tergambar melalui kutipan berikut.

Agar hidupmu tidak sengsara sepertiku, Nak. Aku tidak lulus SD. Tidak bisa apa-apa. Hanya bisa memasak saja. Jangan sepertiku ya Nak. Cukup aku saja yang tidak sekolah. Itu yang selalu Ibuk katakan di hadapan anak-anaknya. (hl.73)

Saat anak pertamanya Isa bisa masuk SMA. Ibu sangat senang. Perjuangan Ibuk dan Bapak memang tak sia-sia yang terungkap melalui kutipan. "Wah gak percaya Isa bisa masuk SMA!" ucap Ibuk dengan bangga. Wajah Ibuk merekah. Satu jalan terjal telah ia lalui bersama Bapak. (hl.121)

Pada saat biaya pendidikan terasa berat, Ibuk tak segan mendatangi kelurahan untuk mengurus surat-surat agar mendapat keringanan biaya sekolah seperti kutipan berikut. 
"Pak, surat ini untuk anak-anak saya. Mereka butuh keringanan untuk uang gedung dan SPP. Bapaknya sudah mencoba yang terbaik sebagai ketua RT. Ini untuk anak-anak saya, Pak. Ini untuk anak-anak saya," pinta Ibuk mencoba meyakinkan Pak Lurah . "Kalau uang kami sudah cukup, saya tidak akan ke sini, Pak. Ini demi masa depan mereka. Biar mereka tidak seperti saya...." (hl.123)

Kutipan tersebut menunjukkan bagaimana Ibuk akan melakukan apapun demi pendidikan anak-anaknya, demi menjamin masa depan anakanaknya, demi melindungi mimpi anakanaknya.

Ibuk juga merupakan pelindung bagi anak-anaknya. Ibu selalu melindungi dan menyertai anak-anaknya dengan restu dan doa. Anak-anak terbiasa melakukan apapun dengan disertai doa Ibuk sebagaimana terlukis melalui kutipan berikut.

"Buk doakan aku. Besok ujian!" teriak Nani.

"Aku juga ya Buk, doakan dapat 10 !" teriak Bayek juga.

Sudah menjadi kebiasaan, anakanak Ibuk selalu meminta doa. Isa dan adik-adiknya baru berangkat sekolah setelah Ibuk menjawab, iya, Ibuk doakan. (hl. 131)

Akhirnya, meminta doa restu Ibuk menjadi kebiasaan yang mendarah daging dalam keluarga Ibuk. Doa Ibuk selalu diminta untuk menyertai setiap sendi kehidupan anak-anaknya dari mereka kecil sampai dewasa.

Peran keluarga selanjutnya adalah peran anak-anak. Bapak dan Ibuk memiliki lima anak yaitu Isa, Nani,
Bayek, Rini dan Mira. Setiap anak memiliki peran masing.

Isa sebagai anak sulung selalu menjadi panutan adik-adiknya. Banyak kebiasaan-kebiasaan baik yang ditularkan Isa kepada adik-adiknya. Salah satunya mengenai kebiasaan belajar sebagaimana kutipan berikut.

Setelah makan siang, Isa langsung mengerjakan PR dan mempersiapkan buku-buku untuk pelajaran besok. Nani dan Bayek mengikuti kebiasaan ini (hl.51)

Isa merupakan anak yang cerdas. Oleh karena itu saat Isa tidak bisa meneruskan pendidikannya ke perguruan tinggi. Isa memilih menjadi guru private dan membantu Bapak dan Ibuk membiayai kuliah Nani dan Bayek. Namun, langkah Isa tidak berhenti di situ. Setelah menikah dan memiliki anak, Isa dapat melanjutkan pendidikan ke jenjang yang lebih tinggi. Isa kuliah dan menjadi guru SD.

Kemudian, Nani, anak kedua. Nani memiliki fisik yang lebih tangguh dibandingkan Isa. Oleh karena itu, Nani lebih aktif membantu Ibuk dengan pekerjaan rumah tangga yang berhubungan dengan kekuatan fisik. Nani juga aktif membantu meringankan beban Ibuk dengan berjualan yang ditunjukkan kutipan berikut. "Nani mulai belajar berdagang. Ia menjual pisang goreng, keripik, atau Citos di sekolah." (hl. 118). Nani merupakan anak pertama yang bisa kuliah, bahkan mengecap S2.

Bayek yang merupakan anak lakilaki satu-satunya merupakan anak yang membawa kebahagiaan bagi keluarganya. Saat Bayek masih kecil ia melihat bagaimana air mana Ibuk 
mengalir. Hal ini membuat Bayek berniat untuk membahagiakan Ibuk dan keluarganya seperti kutipan berikut. "Buk, jangan nangis lagi ya. Kalau Bayek sudah besar, Bayek janji akan membahagiakan Ibuk. Bayek janji, ikrar Bayek dalam hati." (hl.117)

Bayek tidak ingin hanya menjadi sopir angkot seperti Bapak. Ia ingin menjadi orang pintar. Hal ini didukung oleh Ibuk melalui kutipan berikut.

"Kamu sudah gedhe loh Yek. Bentar lagi SMA, kuliah dan kerja. Kalau bisa jangan jadi sopir kayak Bapakmu. Lek iso, senengno Bapakmu ambek dulur-dulurmu yo Le!" pesan Ibuk (hl. 130)

Kutipan tersebut menunjukkan harapan Ibuk agar Bayek menjadi orang sukses. Hal ini seiring dengan keinginan Bayek membahagiakan keluarganya.

Harapannya terkabul saat ia mendapat PMDK ke IPB Bogor. Keluarganya mendukung penuh dan Bapak ikhlas melepas angkotnya untuk biaya kuliah Bayek. Saat lulus, Bayek menjadi lulusan terbaik di jurusannya sebagaimana digambarkan kutipan berikut.

Dalam langkahnya, ia ingin mengatakan kepada Ibuk bahwa angkot yang dijual tidak kemanamana. Angkot yang dijual adalah investasi untuk hidup mereka. Angkot yang dijual adalah masa depan mereka. Menjadi lulusan terbaik adalah kado untuk Ibuk, Bapak, dan keempat saudara perempuan yang telah memberikan jiwa dan hati mereka untuk Bayek. (hl. 136)

Kutipan tersebut menggambarkan bahwa Bayek sangat menyadari perjuangan dan kasih sayang keluarganya. Demi biaya kuliahnya, Bapak rela menjual angkot. Untuk itu, Bayek akan membalasnya dan langkah pertama yang ia lakukan adalah dengan menjadi lulusan terbaik.

Kemudian, Bayek memperoleh pekerjaan. Puncak pencapaiannya saat akhirnya Bayek bekerja di New York. Bayek terdorong menerima pekerjaan di New York karena ingin mengubah hidup keluarga besar sebagaimana kutipan berikut.

Inilah saatnya, aku membangun hidupku dan keluargaku. Apa pun itu New York, akan aku hadapi. Bapak dan Ibuk telah memberi segalanya. Hidupnya. Kini saatnya aku berjuang seperti mereka! tekad Bayek. (hl.144)

Kutipan tersebut menunjukkan demi keluarganya, Bayek memilih untuk kerja di luar negeri.

Bayek bekerja di luar negeri selama hampir sepuluh tahun. Selama itu Bayek berhasil mendirikan rumah yang layak untuk orang tuanya, membantu pembangunan rumah keempat saudara perempuannya, membayar hutanghutang, mendirikan kos di tanah warisan yang Bapak peroleh, membantu kakaknya Isa dan adiknya Rini kuliah lagi dan membelikan mobil baru untuk Bapak.

Saat Bapak meninggal, Bayek berjanji akan menjaga Ibuk dan keluarga menggantikan Bapak seperti kutipan berikut.

"Pak, insya Allah, aku akan jaga rumah Pak. aku akan jaga Ibuk, dan semua. Bapak istirahat dulu. Matur suwun, Pak. Matur suwun. Uripe kene wis keangkat kabeh," bisik Bayek. 
Kemudian, selain Isa, Nani dan Bayek, anak Bapak dan Ibuk adalah Rini dan Mira. Rini adalah anak keempat dan Mira anak kelima. Saat Bayek bekerja di Jakarta, Rini bekerja membantu adik Ibuk yang menjadi bidan desa. Mira sudah kelas 2 SMA. Saat Bayek bekerja di luar negeri, Rini bisa kuliah dan menjadi guru SD seperti Isa. Sedangkan, Mira berhasil mencapai jenjang S2.

\section{PENUTUP}

Setelah melakukan analisis sosiologi sastra terhadap novel Ibuk, dapat ditarik simpulan bahwa fungsi keluarga di dalam novel Ibuk mencakup dan menunjukkan fungsi biologis, fungsi psikologis, fungsi sosial budaya/sosiologi, fungsi sosial, dan fungsi pendidikan.

Bapak, Ibuk dan kelima anaknya memerankan peranan keluarga dengan sangat baik. Bapak sebagai kepala keluarga berperan sebagai pencari nafkah, pelindung dan pemberi rasa aman. Bapak merupakan pekerja keras dan sosok yang bertanggung jawab.
Kerja kerasnya membuat anak-anaknya meniru kerja kerasnya.

Ibuk berperan sebagai istri dan ibu yang baik, mengurus rumah tangga, mengasuh dan mendidik anak-anaknya dengan kelembutan dan penuh kasih sayang. Ibuk menjamin anak-anaknya bisa terus sekolah. Bahkan, sampai jenjang tertinggi. Ia tidak ingin anakanaknya putus sekolah dan tidak mendapat pendidikan yang layak seperti dirinya.

Kemudian, anak-anak pun merupakan anak-anak yang baik yang akhirnya bisa membanggakan orangtuanya. Dari awal, mereka ingin keluar dari kesulitan hidup dan ingin membahagiakan orang tua mereka.

Keluarga dalam novel Ibuk yang terdiri dari Bapak, Ibuk dan kelima anaknya menunjukkan betapa mereka saling menyayangi, saling mendukung dan melengkapi sehingga akhirnya mereka bisa meraih kehidupan yang lebih baik bersama-sama.

\section{DAFTAR PUSTAKA}

Endraswara, Suwardi. 2004. Metodologi Penelitian Sastra. Yogyakarta: Pustaka Widyatama

Departemen Pendidikan Nasional. 2008. Kamus Besar Bahasa Indonesia Pusat Bahasa. Edisi IV. Jakarta: PT Gramedia Pustaka Utama

Nurgiyantoro, Burhan. 2005. Teori Pengkajian Fiksi. Cetakan kelima. Yogyakarta: Gadjah Mada University Press

Setyawan, Iwan. 2012. Ibuk. Jakarta: PT Gramedia Pustaka Utama

Soekanto, Soerjono. 1993. Kamus Sosiologi. Jakarta: PT. Raya Grafindo Persada 
Fungsi dan Peran Keluarga dalam Novel Ibuk Karya Iwan Setyawan (Nidya Triastuti Patricia)

Ratna, Nyoman Kutha. 2004. Teori, Metode, dan Teknik Penelitian Sastra. Jakarta: PT Gramedia Pustaka Utama

https://id.wikipedia.org/wiki/Keluarga

http:/ / www.kajianpustaka.com/2012/11/definisi-fungsi-dan-bentuk-keluarga.html

http:/ / citrarhmdn.blogspot.co.id/2014/11/pengertian-bentuk-fungsi-peranan-dan.html

http:/ / fajar-alvian.blogspot.co.id/2011/10/pengertian-individu-keluarga-dan.html 